\title{
Sales Promotion in Khivraj Motors
}

\author{
Gowtham Ashirvad Kumar, A. Ravikumar, D. Raviteja
}

\begin{abstract}
Marketing is the way toward finding and making an interpretation of shopper needs into item and administration determinations and after that thus making it feasible for increasingly more of customers to appreciate increasingly more of these items and administrations. The principle point of the examination is to reveal new relationship and recognize any issue that may emerge in future. Henceforth, exploratory research is been led. Investigative research as its name infers attempts of investigating the likelihood of doing research regarding a matter where because of absence of existing learning confining and testing the speculations is troublesome.
\end{abstract}

\section{INTRODUCTION}

"Marketing is a social and managerial process by which individuals and groups obtain what they need and want, through creating, offering and exchanging products of value with others".

- Philip Kotler.

Marketing comprises of investigating advertising openings, looking into and choosing objective markets, structuring promoting procedures, arranging showcasing programs and sorting out, actualizing and controlling promoting exertion [1-4].

Organizations need to distinguish long and transient showcasing openings and research the chose market by estimating and guaging appeal of the given market. Having chosen the market, the organizations need to build up a separating and situating technique for the objective market. The promoting system must be changed into advertising programs by settling on showcasing uses and the advertising blend. The last advance is sorting out the advertising assets and actualizing and controlling the showcasing plan [5-7].

\section{Marketing MiX}

Marketing mix is the collection of marketing instruments a company utilizes in the target market to achieve its marketing goals. McCarthy has developed a four-factor marketing tool ranking recognized as the marketing mix's $4 \mathrm{P}$ 's [8-11]

\section{A. Product}

Product represents the concrete business offer of the company, including product quality, layout, characteristics, branding and packaging. It deals with the growth of fresh

Revised Manuscript Received on July 22, 2019.

Gowtham Ashirvad Kumar, Department of Management Studies, Bharath Institute of Higher Education and Research, Chennai, Tamilnadu, India

A. Ravikumar, Department of Management Studies, Bharath Institute of Higher Education and Research, Chennai, Tamilnadu, India

D. Raviteja, department, Name of the affiliated College or University/Industry, City, Country. Email: xyz3@blueeyesintlligence.org products, product life cycle, product blend, branding and related product facilities.

\section{B. Price}

Price is the product's currency value. Price is about choosing sales goals, setting price, payment strategies, and conditions of loan. It is crucial for clients as it chooses the price to be paid by the client in order to obtain the importance of the item.

\section{Place}

This marketing tool represents the different operations undertaken by the business to render the item accessible and accessible to the client. It includes industry size, channel choice and governance, storage and physical delivery with the ultimate goal of delivering the company's bid to the target market effectively. This marketing tool relates to comfort to the client.

\section{Promotion}

Promotion stands for different operations that the business undertakes to connect to the target market and encourage its products. It includes communication programs such as direct marketing, advertising, promotion of revenues.

\section{Statement of the Problem}

The venture is for the most part embraced to ponder the deals limited time methodologies at Khivraj Motors Pvt. Ltd. The expectation of the investigation is to discover what characteristics require further improvement so as to make the item increasingly ideal in the market. [12].

The principle point of the examination is to reveal new relationship and recognize any issue that may emerge in future. Henceforth, exploratory research is been led. Investigative research as its name infers attempts of investigating the likelihood of doing research regarding a matter where because of absence of existing learning confining and testing the speculations is troublesome. In the present crowed commercial center where items and administrations are touting themselves to be the best, it is fundamental to catch everyone's eye. The examination was attempted to investigate how an organization or brand can guarantee a store that sticks out and not lose all sense of direction in the group [13-18].

\section{OBJECTIVES OF THE STUDY}

1. To investigation the different special procedure received by Khivraj Motors Pvt. Ltd.

2. To discover the recording of Khivraj Motors Pvt. Ltd. 
Concerning different players in the market.

3. To watch and comprehend the training pursued by Khivraj Motors Pvt. Ltd.

4. To investigation the exercises of every single division of the association [19-21].

\section{ScOpe OF THE STUdY}

This task was attempted for a particular period in Khivraj Motors Pvt. Ltd.Mount Road Anna Salai, Chennai. It is an activity that is very much arranged into the educational plan giving the specialist a significant chance to comprehend the working elements of the association and to trial and show the as of late obtained administration and organization aptitudes.

The possibility of the Automobile part in India appears to be sure. The Indian Automobile industry has stirred to intriguing occasions! The most recent ten years have seen changes in the showroom of Cars.

(The title of the study is - "A STUDY ON SALES PROMOTION of 4W in Khivraj Motors Pvt Ltd (Mt Road, Anna Salai)".

\section{Limitations}

1. "Change is Constant" principle of nature. Consequently, the investigation attempted may not hold useful for longer term.

2. The investigation was led under the supposition that the data given by ASSENTERS is bona fide.

3. The examination and recommendation are given uniquely regarding promoting perspectives as specialized proposal as for the item couldn't be given.

4. Confidential issues were not revealed by the organization.

5. There were time limitations [22-28].

\section{RESEARCH METHODOLOGY}

An assortment of strategies for study have been received by the scientist to satisfy the destinations of the examination.

- In request to have a superior handle of the investigation, the specialist turned into a sharp onlooker, concentrating the different parts of the association.

- To have a more extensive viewpoint of the examination, the scientist went to the "2 ka 4" conspire display at Palace Grounds wherein the results of Khivraj engines Pvt. Ltd. were shown.

- In request to discover the market substances, the analyst visited the showrooms of specific organizations having practically comparative item profile as that of Khivraj engines Pvt. Ltd. To name of few Maruti Suzuki, zulekha engines pvt ltd and so on.

- With a view to comprehend the mash of the issue and to discover the ground substances, the analyst framed a timetable explicitly for the arrangement of respondents. The analyst met the respondents by and by, talked with them and made them to fill the poll [29-33].
Graph 4 This graph is showing the Competitor's

\section{Strength}

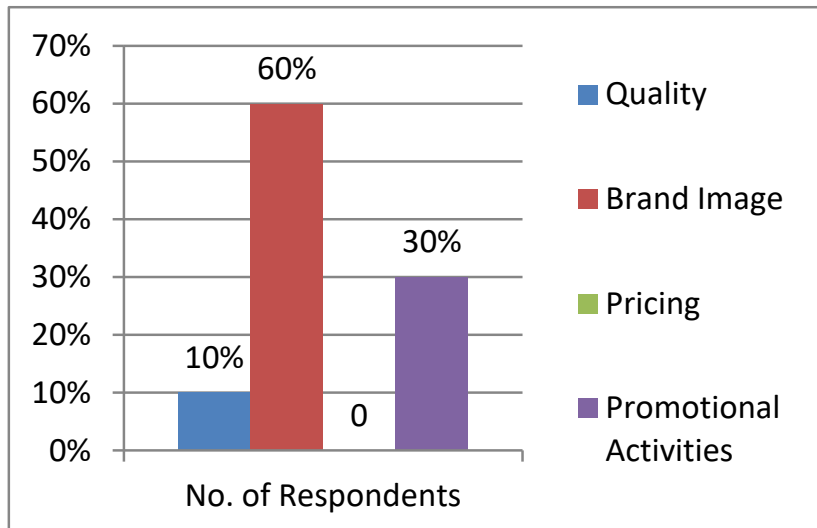

Interpretation

Many of the assenter opines that brand picture is the quality of the contenders.

$10 \%$ of the assenter are of the feeling that the contender's quality will be Quality.

$30 \%$ of the assenter opine that limited time exercises are the quality of the contenders.

$60 \%$ of the assenter opine that brand picture is the quality of the contenders

Larger part of the assenter is of the assessment that the pace of items are of good and is at standard with different contenders having brand names.

Larger part of the assenter for example $54 \%$ are of the assessment that the pace of items are of good as for different contenders.

$46 \%$ of the assenter opine that the pace of items are of generally excellent concerning different contenders.

None of the assenter are of the conclusion that the pace of items are of reasonable or poor concerning different contenders

Graph 5 Quality of the products of Khivraj Motors with respect to other competitors

\section{No. of Respondents}

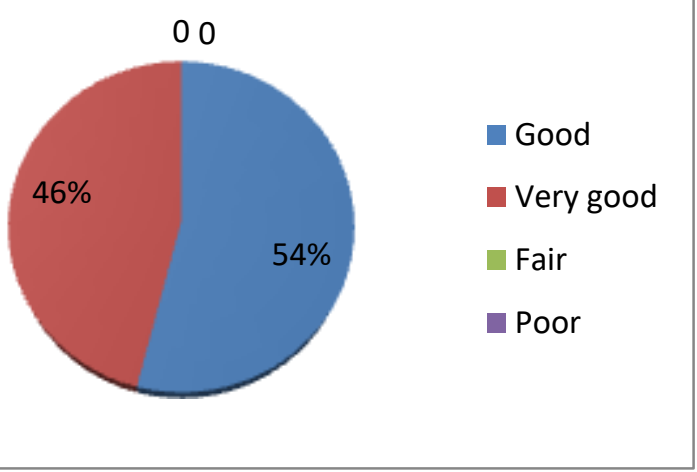

Interpretation

Dominant part of the assenters is of the assessment that the pace of items are of fine and is at standard with different contenders 
Dominant part of the respondents for example $54 \%$ are of the assessment that the pace of items are of good as for different contenders.

$46 \%$ of the respondents opine that the pace of items are of excellent concerning different contenders.

None of the respondents are of the sentiment that the pace of items are of reasonable or poor concerning different contenders

Graph 6 This graph is showing Kinds of commodities sold more per month

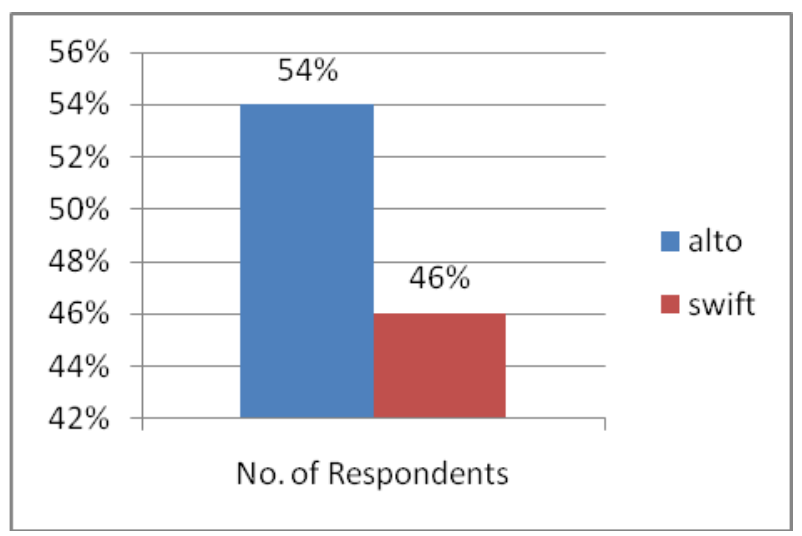

Interpretation

- $\quad$ Both Alto and swift are sold per month in equal ratio.

- $54 \%$ of the assenter are of the opinion that Alto is sold more per month.

\section{RESULTS}

1. The organization receives an assortment of limited time strategies, for example, paper addition, telemarketing, show slows down, taking an interest in displays, standard mail, introductions and showrooms. 2. Though brand names like Hyundai and Honda came into the image however the reality uncovers that there is no predominant player in the market. So every player is competing with one another to catch a bigger pie in the business sectors.

3. The items are showcased through direct advertising (showroom) and sellers are not associated with the promoting procedure up until this point.

4. The exercises did by every single division of the association is efficient.

\section{DISCUSSION}

- With the huge range of particular choice accessible in market, the customer isn't generally tied for decision.

- Japanese producers have now entered the Indian markets. More or less, this way to state that the challenge is extreme.

- Many marked organizations redistribute the items due to which the conveyance time of the item requested is extended. In this regard, Khivraj Motors has an additional bit of leeway.
- Khivraj Motors offers Exchange the old vehicles an ideal rate with new vehicles. This gives it an edge over the others.

- "Quality never comes shoddy". This is valid and yet, it is additionally obvious that quality can come at a sensible cost. Concerning the quality, results of Khivraj Motors are at standard with different players having brand names

- With respect to home Delivery, the greater part of the organizations have institutionalized items yet the Khivraj Motors are altered. This can be appropriately set apart as the quality of the organization.

- Maruti SX4, Alto and Swift are sold more every month. Along these lines, this region needs more prominent core interest.

- Sensible evaluating, tweaked items, quality in separating the results of the association from that of the others.

- Aside from cost of the item, structure and conveyance time of the item requested assume an essential job in activating out interest age of the item.

- Markdown is given on rehash buy.

- The organization does not hold fast to stringent standard while giving markdown on rehash buy.

- The objective buyers are the upper working class, Government Employees and Private Sector representatives.

\section{CONCLUSION}

"No man has the privilege to manage what other men ought to see, make or produce, however all ought to be urged to uncover themselves, their recognitions and feelings and constructs trust in their imaginative soul!"

This moving idea of Ansell Adams is very much valued by new style advertising associations which comprehend that "crates and lines" structures can't drive an incentive in quick moving conditions. Most likely, Khivraj Motors Pvt. Ltd. is one of them since they put stock in cooperation. Today, the need of the Indian shopper develops past "roti, kapada aur makaan". The game in the Automobile business is never again outfitting. It is about "Grown-up toy". Herein, lays the importance of the Japanese proverb which says - "Thinking without action is a daydream and action without thinking is a nightmare".

\section{REFERENCES}

1. G. BharthVajan R., Ramachandran S.,Psychographic dimensions of training,2016,International Journal of Pharmacy and Technology,V-8,I-4,P-23727-23729

2. Balakrishnan P., Bharthvajan R.,A study on human resource planning in hospitals in Chennai City,2014,International Journal of Applied Engineering

Research,V-9,I-22,P-7503-7507

3. Priyadarsini P., Bharthvajan R.,Role of emotional intelligence training 
programme in reducing the stress of the nurses,2014,International Journal of Applied Engineering Research,V-9,I-22,P-7411-7421

4. Kerinab Beenu G., Bharthvajan R.,Empirical analysis on the cosmetic buying behavior of young women in South India,2014,International Journal of Applied Engineering Research,V-9,I-22,P-7361-7366

5. Balakrishnan P., Bharthvajan R.,Whistling in the wind,2014,International Journal of Applied Engineering Research,V-9,I-22,P-7586-7593

6. Krishnan B., Peter M.,Health hazards of Indian Bpo employee-an alarming issue,2014,International Journal of Applied Engineering Research,V-9,I-22,P-7336-7341

7. Kerinab Beenu G.H., Peter M.,Role of insurance in economic development,2014,International Journal of Applied Engineering Research,V-9,I-22,P-7532-7539

8. Balakrishnan P., Peter M., Priyadarsini P.,Efficiency of safety measures for wellbeing of employees in manufacturing industry,2014,International Journal of Applied Engineering Research,V-9,I-22,P-7376-7382

9. Anbarasi M., Praveen Kumar S.,Online sales promotions of herbal products and its effectiveness towards tanisha.com,2019,Indian Journal of Public Health Research and Development,V-10,I-1,P-195-200

10. Anbarasi M., Praveen Kumar S.,Various online marketing and promotions strategies to improve the validation towards the organic products in the pharmaceutical sectors, 2019,Indian Journal of Public Health Research and Development,V-10,I-1,P-263-269

11. Loganathan R., Praveen Kumar S.,Grievance handling a key factor for solving issues of employees in an organization,2014,International Journal of Applied Engineering Research,V-9,I-22,P-7483-7491

12. Loganathan R., Praveen Kumar S.,Study on preference of private label brands in super and Hypermarkets,2014,International Journal of Applied Engineering Research,V-9,I-22,P-7327-7335

13. Smitha M., Praveen Kumar S.,Understanding stress and its managementamong the nurses in Chennai city,2014,International Journal of Applied Engineering Research,V-9,I-22,P-7560-7565

14. Kerinab Beenu G.H., Praveen Kumar S.,A study on the investment behavior of Chennai investors in mutual fund schemes,2014,International Journal of Applied Engineering Research,V-9,I-22,P-7520-7525

15. Loganathan R., Praveen Kumar S.,Retention strategies key for organizational productivity,2014,International Journal of Applied Engineering Research,V-9,I-22,P-7443-7447

16. Pavithra J., Ganesan M., Brindha G.,State wise analysis of microfinance sector in India,2016,International Journal of Pharmacy and Technology,V-8,I-4,P-23417-23432

17. Pavithra J., Ganesan M.,A comparative study on microfinance in India and abroad,2016,International Journal of Applied Business and Economic Research,V-14,I-8,P-5471-5476

18. Pavithra J., Ganesan M.,A study on awareness and impact of micro-financial schemes,2016,International Journal of Applied Business and Economic Research,V-14,I-8,P-5449-5460

19. Senthilmurugan P., Pavithra J.,Consumer preference towards organised retailing with reference to Big Bazaar,2014,International Journal of Applied Engineering Research,V-9,I-22,P-7469-7475

20. Senthilmurugan P., Pavithra J.,Implication of social media marketing in growing healthcare industry,2014,International Journal of Applied Engineering Research,V-9,I-22,P-7448-7456

21. Loganathan R., Pavithra J.,Consumer perception towards private label brand over other brands in super markets and hypermarkets,2014,International Journal of Applied Engineering Research,V-9,I-22,P-7355-7360

22. Kerinab Beenu G., Pavithra J.,Tradeâ€"off between liquidity and profitability in logistics industry,2014,International Journal of Applied Engineering Research,V-9,I-22,P-7398-7401

23. Kerinab Beenu G., Pavithra J.,A study on the prospective consumerâ€ $\mathrm{TM}_{\mathbf{S}}$ perception towards utility cars in Chennai city,2014,International Journal of Applied Engineering Research,V-9,I-22,P-7526-7531

24. Pavithra J., Dilli Babu P., Ambuli T.V.,A study on budgetary control at Maruti Service Masters, Chennai,2014,International Journal of Applied Business and Economic Research,V-12,I-2,P-151-161

25. Pavithra J., Dilli Babu P., Ambuli T.V.,A study on customer satisfaction of retro Garments Pvt Ltd, Chennai,2014,International Journal of Applied Business and Economic Research,V-12,I-2,P-381-391

26. Kerinab Beenu G.H., Pavithra J., Senthilmurugan P.,A study on the influence of promotional activities for TATA ARIA among consumers in Chennai,2014,International Journal of Applied Engineering Research,V-9,I-22,P-7572-7578

27. Vijayaragavan S.P.,An investigative expert that's general FBG sensors, International Journal of Mechanical Engineering and Technology,V-8,I-8,PP-1500-1505,Y-2017

28. Vijayaragavan S.P.,Equalization routing protocol for Wi-Fi sensor strategy,International Journal of Mechanical Engineering and Technology,V-8,I-8,PP-1662-1666,Y-2017
29. Karthik B., Kiran Kumar T.V.U., Vijayaragavan P., Bharath Kumaran E.,Design of a digital PLL using 0.35 $\hat{\mathrm{I}}^{1 / 4 \mathrm{~m}}$ CMOS technology, Middle East Journal of Scientific Research,V-18,I-12,PP-1803-1806,Y-2013

30. Kanniga E., Selvaramarathnam K., Sundararajan M.,Kandigital bike operating system,Middle - East Journal of Scientific Research,V

31. Jasmin M., Vigneshwaran T., Beulah Hemalatha S.,Design of power aware on chip embedded memory based FSM encoding in FPGA,International Journal of Applied Engineering Research,V-10,I-2,PP-4487-4496,Y-2015

32. Jasmin M.,Optimization techniques for low power VLSI circuits,Middle East Journal of Scientific Research,V-20,I-9,PP-1082-1087,Y-2014

33. Jasmin M., Vigneswaran T.,Fuzzy controller for error control of on - Chip communication,2017 International Conference on Algorithms, Methodology, Models and Applications in Emerging Technologies, ICAMMAET 2017,V-2017-January,I-,PP-1-5,Y-2017

\section{AUTHORS PROFILE}

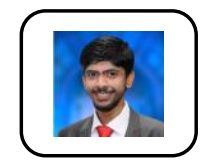

Gowtham Ashirvad Kumar, Associate Professor, Department of Management Studies, Bharath Institute of Higher Education and Research, Chennai, India

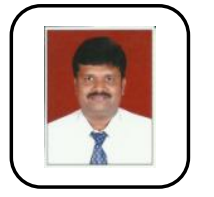

A. Ravikumar, Associate Professor, Department of Management Studies, Bharath Institute of Higher Education and Research, Chennai, India

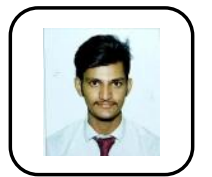

D. Raviteja, Student, Department of Managemen Studies, Bharath Institute of Higher Education and Research, Chennai, India 